\title{
Peningkatan Hasil Belajar Memaparkan Informasi Penting Teks Narasi Sejarah melalui Model Survey, Question, Read, Reflect, Recite (SQ4R) Berbasis Karakter Gemar Membaca Siswa Kelas V SDN Sumberingin 04 Kabupaten Blitar
}

\author{
Indarti Eka Roudhotul Jannah*, Alif Mudiono, Ferril Irham Muzaki \\ Universitas Negeri Malang, Jl. Semarang No. 5 Malang, Jawa Timur, Indonesia \\ *Penulis korespondensi, Surel: indarti.eka.1601516@students.um.ac.id
}

Paper received: 3-3-2021; revised: 24-3-2021; accepted: 28-3-2021

\begin{abstract}
Student 4 grade of Sumberingin 04 elementary school in Blitar regency has difficulty presenting important information about historical narrative text. The difficulties experienced when students could not understand the content contained in reading well. The study was conducted with the aim to improve student learning outcomes on the material to expose the important information narrative text history using a character based SQ4R models to read. The type of research used is class action research (PTK) with two cycles. Results of the study acquired teacher activity cycle I 84 percent, cycle II 98 percent. Students activity cycle I 78 percent, cycle II 94 percent. The knowledge cycle results I 76 percent, cycle II to 89 percent. Skill cycle I 69 percent, cycle II to 89 percent. Results improvement of the thorough attitude of the cycle I 62 percent, self confidence 65 percent, attitude responsibility 62 percent, in cycles II meticulous attitude 89 percent, confidence attitude 89 percent, responsibility attitude 82 percent. Increased character likes reading cycles I 62 percent, cycle II 88 percent.
\end{abstract}

Keywords: the result of learning; explain important information; SQ4R

\begin{abstract}
Abstrak
Siswa kelas V SDN Sumberingin 04 Kabupaten Blitar mengalami kesulitan dalam memaparkan informasi penting teks narasi sejarah. Kesulitan yang dialami disebakan karena siswa tidak bisa memahami isi yang terkandung dalam bacaan dengan baik. Penelitian ini dilakukan dengan tujuan untuk meningkatkan hasil belajar siswa pada materi memaparkan informasi penting teks narasi sejarah menggunakan model SQ4R berbasis karakter gemar membaca. Jenis penelitian yang digunakan adalah Penelitian Tindakan Kelas (PTK) dengan dua siklus. Hasil penelitian diperoleh aktivitas guru siklus I 84 persen, siklus II 98 persen. Aktivitas siswa siklus I 78 persen, siklus II 94 persen. Hasil pengetahuan siklus I 76 persen, siklus II menjadi 89 persen. Hasil keterampilan siklus I 69 persen, siklus II menjadi 89 persen. Hasil peningkatan sikap teliti siklus I 62 persen, sikap percaya diri 65 persen, sikap tanggung jawab 62 persen, pada siklus II sikap teliti 89 persen, sikap percaya diri 89 persen, sikap tanggung jawab 82 persen. Peningkatan karakter gemar membaca siklus I 62 persen, siklus II 88 persen.
\end{abstract}

Kata kunci: hasil belajar; memaparkan informasi penting; SQ4R

\section{Pendahuluan}

Hasil observasi yang dilakukan pada tanggal 12 November 2019 di SDN Sumberingin 04 Kabupaten Blitar terhadap kegiatan pembelajaran di kelas V, terdapat 17 siswa yang terdiri dari 6 siswa laki-laki dan 11 siswa perempuan. Berdasarkan observasi didapatkan hasil bahwa dalam pembelajaran guru menggunakan metode ceramah, tanya jawab dan penugasan. Dapat dijelaskan bahwa pada awal pembelajaran guru mengucapkan salam, berdoa, mengecek kehadiran, melakukan apersepsi dan menyampaikan materi pembelajaran tanpa menyampaikan tujuan pembelajaran. Pada kegiatan inti guru menjelaskan mengenai materi 
dan kegiatan yang akan dilaksankan, kemudian meminta siswa untuk membaca teks narasi sejarah, menandai informasi penting yang terdapat dalam bacaan, dan memaparkan informasi yang telah diperoleh. Dalam kegiatan pembelajaran terlihat siswa kesulitan dalam menentukan dan memaparkan informasi penting, selain itu siswa kurang aktif dan kurang memiliki minat dalam membaca. Selanjutnya dalam kegiatan wawancara yang dilakukan dengan guru kelas $\mathrm{V}$ didapatkan hasil yaitu dalam pembelajaran masih banyak siswa yang mengalami kesulitan akibat minat membaca siswa masih rendah, kemampuan menelaah isi bacaan masih rendah, kurangnya kemampuan siswa dalam membaca pemahaman, kurangnya kemapuan siswa dalam memaparkan menggunakan bahasa sendiri. KKM yang ditetapkan oleh sekolah yaitu 70, dari 17 siswa hanya terdapat 6 siswa atau 35\% yang mencapai nilai ketuntasan, sedangkan sebanyak 11 siswa atau $65 \%$ belum mencapai ketuntasan pada materi memaparkan informasi penting teks narasi sejarah.

Memaparkan informasi merupakan kegiatan menguraikan informasi yang telah diperoleh. Memaparkan informasi penting teks narasi sejarah merupakan materi muatan bahasa Indonesia di kelas $V$ yang terdapat pada kompetensi dasar (KD) 3.5 menggali informasi penting dari teks narasi sejarah yang disajikan secara lisan dan tulis menggunakan aspek: apa, di mana, kapan, siapa, mengapa, dan bagaimana dan kompetensi dasar (KD) 4.5 memaparkan informasi penting teks narasi sejarah menggunakan aspek: apa, di mana, kapan, siapa, mengapa, dan bagaimana serta kosakata baku dan kalimat efektif (Permendikbud No 37 Tahun 2018). Dalam memaparkan informasi sangat dibutuhkan kemampuan siswa dalam menulis. Menurut Supriadin (2018) menulis merupakan keterampilan yang melibatkan perbendaharaan kata, penggunaan tanda baca, penempatan ejaan, serta kemampuan menata kalimat. Selain keterampilan menulis keterampilan membaca juga berperan penting dalam pembelajaran memaparkan informasi penting teks narasi sejarah. Menururt Mulyati (2015:1.23) kemampuan membaca penting sekali bagi proses menulis atau memaparkan sebuah informasi, karena sebelum menyampaikan gagasan atau informasi dalam bentuk tulis seseorang harus melakukan proses membaca untuk memahami isi dalam sebuah bacaan.

Dalam mengatasi permasalahan-permasalahan tersebut dilakukan upaya meningkatkan pembelajaran yang dapat menumbuhkan motivasi, aktivitas belajar, dan dapat meningkatkan hasil belajar siswa. Upaya yang dilakukan yaitu dengan menerapkan model pembelajaran SQ4R, model ini merupakan pengembangan dari model survey, question, read, recite, review (SQ3R). Model pembelajaran SQ4R merupakan strategi membaca yang dapat mengembangkan metakognitif siswa, yaitu dengan memberikan tugas siswa untuk membaca bahan belajar bersama-sama (Rahayu dkk, 2014). Model pembelajaran ini memiliki beberapa kelebihan, menurut Sohimin (2016) kelebihan tersebut yaitu: (1) dapat menumbuhkan rasa ingin tahu mengenai materi yang akan dipelajari sehingga mampu membangkitkan semangat belajar; (2) dapat melibatkan siswa secara aktif; (3) siswa mampu berfikir kritis dalam pembelajaran; (4) materi yang dipelajari dapat diingat dalam waktu yang lama.

Sebagai pelaksana pembelajaran guru harus menguasai langkah-langkah dalam pembelajaran menggunakan model SQ4R agar dapat menciptakan pembelajaran yang bermakana dan dapat meningkatkan hasil belajar memaparkan informasi penting teks narasi sejarah. Adapaun langkah-langkah model pembelajaran SQ4R menurut Sohimin (2016) adalah sebagai berikut: (1) survey mencermati teks bacaan dan menandai serta mencatat kata kunci; (2) question, membuat daftar pertanyaan tentang bahan bacaan; (3) read, membaca teks bacaan untuk menjawab pertanyaan-pertanyaan yang telah dirumuskan sebelumnya; (4) 
reflect, melaksanakan aktivitas memberikan contoh dari bahan bacaan dan membayangkan konteks aktual yang relevan; (5) recite, mengutarakan kembali berbagai informasi baik yang berupa jawaban atas pertanyaan ataupun informasi lain yang dianggap penting; (6) review, meninjau ulang secara menyeluruh.

Dalam penelitian ini diharapkan dapat menumbuhkan karakter gemar membaca siswa. Karakter gemar membaca siswa harus sudah ditumbuhkan saat awal proses pembelajaran, karena dalam materi memaparkan informasi penting sangat dibutuhkan minat siswa dalam membaca untuk memahami isi bacaan dengan tepat. Menurut Zainuddin (2012:40) gemar membaca adalah kebiasaan menyediakan waktu untuk membaca berbagai bacaan yang dapat memberikan kebajikan bagi dirinya.

Penelitian yang menerapkan model pembelajaran SQ4R juga pernah dilakukan oleh Atmaja (2019) dengan judul peningkatan hasil belajar memahami isi dan amanat puisi menggunakan model survey, question, read, reflect, recite, review (SQ4R) pada siswa kelas IV SDN Pojok 02 Kabupaten Blitar. Penelitian tersebut memperoleh hasil pada siklus I rata-rata persentase nilai pengetahuan 75\% dengan persentase KBK 55\% dan pada siklus II meningkat menjadi $85 \%$ dengan persentase KBK $90 \%$. Pada siklus I persentase rata-rata nilai keterampilan 58\% dan siklus II meningkat menjadi $83 \%$.

Berdasarkn uraian tersebut, guru perlu menerapkan model pembelajaran SQ4R agar kegiatan pembelajarn lebih aktif dan siswa dapat dapat termotivasi dalam kegiatan pembelajaran. Penerapan langkah-langkah model SQ4R yang baik juga akan berpengaruh terhadap peningkatan hasil belajar siswa serta dapat meningkatkan karakter gemar membaca siswa.

\section{Metode}

Penelitian ini dilaksanakan di SDN Sumberingin 04 Kabupaten Blitar. Penelitian ini menggunakan pendekatan kualitatif dengan jenis Penelitian Tindakan Kelas (PTK). Menurut Arikunto, dkk (2016) penelitian tindakan kelas merupakan penelitian yang mengutamakan proses pembelajaran, penelitian ini dilaksanakan oleh guru untuk memperbaiki kualitas pembelajaran di kelasnya. Penelitian ini menggunakan siklus dan tahapan yang dikemukakan oleh Kemmis \& Mc. Taggart (dalam Arikunto 2013). Penelitian dilaksanakan sebanyak 2 siklus, masing-masing siklus terdiri dari 2 pertemuan. Setiap siklus terdiri dari tahap perencanaan, pelaksanaan, pengamatan, dan refleksi.

Data yang digunakan dalam penelitian ini meliputi data proses dan data hasil belajar siswa. Data proses diperoleh melalui pengamatan aktivitas guru dan aktivitas siswa dengan menggunakan model SQ4R. Data hasil belajar siswa diperoleh dari penilaian aspek pengetahuan, keterampilan, sikap, dan karakter gemar membaca. Data hasil belajar pengetahuan diperoleh dari LKK dan tes evaluasi, data hasil belajar keterampilan diperoleh dari hasil memaparkan informasi penting teks narasi sejarah secara tulis, sedangkan hasil belajar sikap dan karakter gemar membaca diperoleh dari hasil pengamatan selama proses pembelajaran berlangsung. Subjek dari penelitian ini adalah guru dan siswa kelas V SDN Sumberingin 04 Kabupaten Blitar yang berjumlah 17 siswa, terdiri dari 6 siswa laki-laki dan 11 siswa perempuan. Pengumpulan data pada penelitian ini melalui observasi, wawancara, tes, dokumentasi, dan catatan lapangan. Setelah semua data terkumpul maka dilakukan analisis data. Analisis data yang digunakan yaitu analisis data kualitatif menurut Miles \& Huberman 
(dalam Sugiyono, 2015:401) yang menyatakan bahwa ada tiga proses yang harus dilalui saat menganalisis data yaitu reduksi data, penyajian data, dan penarikan kesimpulan.

\section{Hasil dan Pembahasan}

\subsection{Hasil}

Hasil belajar siswa dalam memaparkan informasi penting teks narasi sejarah tahap pratindakan dikategorikan perlu bimbingan karena dari 17 siswa, 11 siswa atau 65\% diantaranya tidak mencapai kriteria ketuntasan minimal (KKM) yang ditetapkan yaitu 70 . Sementara siswa yang mencapai KKM hanya 35\% atau 6 siswa. Rendahnya hasil belajar materi memaparkan informasi penting teks narasi sejarah disebabkan karena siswa kesulitan dalam menentukan informasi penting, kesulitan dalam memahami isi bacaan, siswa kurang termotivasi saat pembelajaran, minat membaca siswa masih rendah, kurangnya kemampuan siswa dalam membaca pemahaman, saat pembelajaran siswa tidak memperhatikan materi yang disampaikan, dan siswa kesulitan dalam memaparkan menggunakan bahasa sendiri.

Setelah dilakukan tindakan pada siklus I diperoleh hasil rata-rata persentase aktivitas guru sebesar $84 \%$ dengan kriteria keberhasilan baik dan rata-rata persentase aktivitas siswa sebesar 78\% dengan kriteria keberhasilan cukup. Nilai rata-rata pengetahuan siswa yaitu 80 dengan persentase ketuntasan belajar klasikal (KBK) sebesar 76\% termasuk kriteria ketuntasan cukup. Nilai rata-rata keterampilan siswa yaitu 69 dengan persentase KBK 69\% termasuk kritetria ketuntasan kurang. Sedangkan rata-rata persentase sikap teliti siswa sebesar $62 \%$ dengan kriteria ketuntasan kurang, rata-rata persentase sikap percaya diri sebesar $65 \%$ dengan kriteria ketuntasan kurang, dan rata-rata persentase sikap tanggung jawab siswa sebesar $62 \%$ dengan kriteria ketuntasan kurang. Penanaman karakter gemar membaca sudah muncul pada siklus I dengan rata-rata 62 dan pencapaian persentase sebesar $62 \%$ termasuk kriteria ketuntasan kurang. Pada saat pelaksanaan siklus I masih terdapat beberapa kekurangan, antara lain: (1) hendaknya guru mengarahkan siswa untuk memberikan tanggapan saat ada siswa lain yang menyampaikan hasil diskusi; (2) pada akhir kegiatan hendaknya guru meminta siswa untuk membuat kesimpulan hasil belajar, memberikan kesempatan kepada siswa untuk bertanya dan menyampaikan kesan pembelajaran; (3) hendaknya guru lebih memperhatikan pengelolaan kelas; (4) guru harus meningkatkan pendekatan kepada siswa; (5) guru harus meningkatkan pemberian penguatan kepada siswa yang kurang percaya diri.

Pada siklus II diperoleh temuan yaitu rata-rata persentase aktivitas guru meningkat menjadi 98\% dengan kriteria ketuntasan sangat baik, dan rata-rata persentase aktivitas siswa meningkat menjadi 94\% dengan kriteria keberhasilan sangat baik. Nilai pengetahuan siswa mengalami peningkatan yaitu mencapai rata-rata 89 dengan persentase KBK sebesar $89 \%$ termasuk kriteria ketuntasan baik. Nilai rata-rata keterampilan siswa yaitu 79 dengan persentase KBK sebesar $89 \%$ termasuk kriteria ketuntasan baik. Sedangkan nilai rata-rata persentase sikap teliti siswa sebesar $89 \%$ dengan kriteria ketuntasan baik, rata-rata persentase sikap percaya diri siswa sebesar $89 \%$ dengan kriteria ketuntasan baik, dan ratarata sikap tanggung jawab siswa sebesar $82 \%$ dengan kriteria ketuntasan baik. Peningkatan juga terjadi pada karekter gemar membaca yang mencapai rata-rata 87 dengan persentase sebesar $88 \%$ termasuk kriteria ketuntasan baik. 
Hasil analisis data pada siklus II menunjukkan bahwa aktivitas guru, aktivitas siswa, dan hasil belajar siswa dalam memaparkan informasi penting teks narasi sejarah memalui model SQ4R berbasis karakter gemar membaca mengalami peningkatan. Hal ini terjadi karena guru telah melaksanakan pembelajaran sesuai dengan langkah-langkah dalam rencana pelaksanaan pembelajaran yang telah disiapkan sebelumnya, selain itu kekurangan-kekurangan pada siklus I telah diperbaiki pada pelaksanaan siklus II. Pada pelaksanaan siklus II semua siswa telah terlibat aktif dalam pembelajaran dan telah memiliki kepercayaan diri dalam menyampaikan pendapat. Selain itu antusias siswa dalam membaca sudah cukup baik hal ini dapat dilihat dari meningkatnya kemampuan siswa dalam memahami isi sebuah bacaan.

\subsection{Pembahasan}

Penerapan model SQ4R berbasis karakter gemar membaca pada pelaksanaan pembelajaran bahasa Indonesia materi memaparkan informasi penting teks narasi sejarah dilaksanakan dalam 2 siklus dengan masing-masing siklus terdiri dari 2 kali pertemuan. Pada siklus I pertemuan 1 aktivitas guru dalam menerapkan model SQ4R mencapai 80\% dengan kriteria keberhasilan baik. Hal ini terjadi karena guru melewatkan beberapa langkah dalam pembelajaran. Langkah-langkah tersebut yaitu, di awal pembelajaran guru tidak meyampaikan tujuan pembelajaran, karena siswa masih sulit untuk dikondisikan. Pada saat kegiatan inti guru tidak memberikan kesempatan kepada siswa untuk memberikan tanggapan kepada siswa lain yang menyampaikan hasil pekerjaannya, guru tidak melakukan karena kurangnya pengkondisian siswa dan kurang memperhatikan manajemen waktu. Di akhir pembelajaran guru tidak mengajak siswa untuk membuat kesimpulan bersama, tidak memberikan kesempatan kepada siswa untuk bertanya dan menyampaikan kesan pembelajaran, serta tidak menginformasikan mengenai materi pada pertemuan selanjutnya. Hal ini terjadi karena waktu pembelajaran hampir habis. Guru juga kurang memberikan motivasi saat siswa mengerjakan tugas, karena guru hanya terfokus pada siswa yang benar-benar mengalami kesulitan.

Pada siklus I pertemuan 2 aktivitas guru mengalami peningkatan menjadi 88\% dengan kriteria keberhasilan baik. Guru telah memperbaiki beberapa kesalahan yang terjadi pada pertemuan 1, yaitu diawal pembelajaran guru telah menyampaikan tujuan pembelajaran, diakhir pembelajaran guru telah menyampaikan materi pembelajaran pada pertemuan selanjutnya, selain itu guru telah memotivasi siswa saat mengerjakan tugas meskipun guru kurang memberikan penguatan terhadap hasil pekerjaan siswa. Namun guru belum mengajak siswa untuk menyimpulkan hasil belajar, memberikan kesempatan untuk bertanya dan menyampaikan kesan pembelajaran, guru kurang mendekatkan diri dengan siswa, selain itu guru belum memberikan kesempatan kepada siswa untuk menanggapi hasil pekerjaan siswa lain. Berdasarkan pelaksanaan siklus I maka diperoleh rata-rata aktivitas guru sebesar $84 \%$ dengan kriteria keberhasilan baik.

Siklus II pertemuan I aktivitas guru mengalami peningkatan menjadi 96\% dengan kriteria keberhasilan sangat baik. Karena guru telah memperbaiki pembelajaran berdasarkan hasil refleksi pada siklus I. Pada pertemuan ini masih terdapat langkah yang terlewatkan, yaitu guru tidak mengajak siswa untuk menyimpulkan hasil belajar, dikarenakan guru merasa semua siswa telah memahami materi yang telah dipelajari. Pada siklus II pertemuan 2 aktivitas guru mencapai $100 \%$ dengan kriteria sangat baik. Hal ini menandakan guru telah melaksanakan semua langkah-langkah pembelajaran berdasarkan rencana pelaksanaan 
pembelajaran yang sebelumnya telah disusun. Berdasarkan perolehan pada siklus II maka diperoleh rata-rata persentase sebesar $98 \%$ dengan kriteria keberhasilan sangat baik.

Pembelajaran yang dilakukan guru sudah berjalan lancar dan sesuai dengan langkahlangkah model pembelajaran SQ4R seperti yang dikemukakan oleh Sohimin (2016:191) adalah sebagai berikut: (1) survey, mencermati teks bacaan dan menandai serta mencatat kata kunci; (2) question, membuat daftar pertanyaan tentang bahan bacaan; (3) read, membaca teks bacaan untuk menjawab pertanyaan-pertanyaan yang telah dirumuskan sebelumnya; (4) reflect, melaksanakan aktivitas memberikan contoh dari bahan bacaan dan membayangkan konteks aktual yang relevan; (5) recite, mengutarakan kembali berbagai informasi, baik yang berupa jawaban atas pertanyaan ataupun informasi lain yang dianggap penting; (6) review, meninjau ulang secara menyeluruh.

Aktivitas siswa siklus I pertemuan 1 sebesar 73\% dengan kriteria keberhasilan cukup. Pada pertemuan ini siswa kurang aktif dalam pembelajaran, siswa kurang memperhatikan saat guru menjelaskan, sebagian besar siswa tidak antusias saat membaca, ada 2 kelompok yang kesulitan menentukan informasi penting, ada 3 kelompok yang kesulitan dalam membuat kalimat tanya apa, mengapa, dan bagaimana, siswa kesulitan dalam memaparkan informasi penting, siswa kurang percaya diri saat menyampaikan pendapat, 6 orang siswa memerlukan waktu tambahan dalam mengerjakan soal evaluasi karena bermain-main dan tidak memperhatikan waktu. Pada siklus I pertemuan 2 aktivitas siswa meningkat menjadi 82\% dengan kriteria keberhasilan baik. Pada pertemuan ini siswa mulai aktif dalam kegiatan pembelajaran meskipun masih ada siswa yang pasif dalam kegiatan kelompok, siswa mulai antusis ketika diminta membaca, beberapa siswa mengalami peningkatan sikap percaya diri saat menyampaikan pendapat. Namun masih ada beberapa siswa yang mengalami kesulitan dalam membuat kalimat tanya bagaimana dan mengapa. Selain itu beberapa siswa masih kesulitan dalam memaparkan informasi penting. Dari perolehan persentase pada setiap pertemuan, maka diperoleh rata-rata aktivitas siswa pada siklus I sebesar 78\% dengan kriteria keberhasilan cukup.

Aktivitas siswa pada siklus II pertemuan 1 meningkat menjadi 90\% dengan kriteria keberhasilan sangat baik. Beberapa kekurangan pada siklus I telah diperbaiki pada siklus ini. Meskipun masih ada beberapa kekurangan yang ditemukan pada pertemuan ini yaitu, masih ada 2 orang siswa yang kurang antusias saat membaca, masih ada beberapa siswa yang kesulitan dalam memaparkan informasi. Pada siklus II pertemuan 2 aktivitas siswa mengalami peningkatan menjadi 98\% dengan kriteria keberhasilan sangat baik. Pada pertemuan ini semua siswa telah terlibat aktif dalam kegiatan pembelajaran, semua siswa mengalami peningkatan sikap percaya diri, selain itu antusias siswa dalam kegiatan membaca juga mengalami peningkatan. Pada saat kegiatan tanya jawab ada beberapa siswa yang berani mengkritisi jawaban siswa lain yang kurang sesuai. Siswa telah memahami materi pembelajaran yang diberikan dengan baik. Namun pada pertemuan ini ada salah satu siswa yang kurang memahami cara membuat kalimat tanya dengan unsur $5 \mathrm{~W}+1 \mathrm{H}$, dikarenakan tidak mengikuti pembelajaran pada pertemuan-pertemuan sebelumnya, selain itu ada 2 orang siswa yang membutuhkan waktu tambahan saat mengerjakan evaluasi. Diperoleh rata-rata persentase aktivitas siswa pada siklus II sebesar 94\% dengan kriteria sangat baik.

Aktivitas siswa mengalami peningkatan sesuai dengan pendapat Sohimin (2016:194) yang berkaitan dengan kelebihan-kelebihan model SQ4R yaitu: (1) dapat menumbuhkan rasa 
ingin tahu mengenai materi yang akan dipelajari, sehingga mampu membangkitkan semangat belajar; (2) dapat melibatkan siswa secara aktif; (3) siswa mampu berfikir kritis dalam pembelajaran; dan (4) materi yang dipelajari dapat diingat dalam waktu yang lama.

Model SQ4R berbasis karakter gemar membaca dapat meningkatkan hasil belajar siswa baik dari aspek pengetahuan, keterampilan, sikap, dan karakter gemar membaca. Hal ini dibuktikan dari hasil belajar siswa yang mengalami peningkatan dari tahap pratindakan, siklus I, dan siklus II. Adanya peningkatan hasil belajar tersebut sesuai dengan pendapat Susanto (2016:5) yang menyatakan bahwa, hasil belajar adalah perubahan yang terjadi pada seorang individu, baik yang meliputi pengetahuan, sikap, dan keterampilan sebagai hasil dari proses belajar. Persentase ketuntasan belajar klasikal pada tahap pratindakan sebesar 35\% dengan kriteria ketuntasan perlu bimbingan. Hal ini menunjukkan bahwa ketuntasan kelas belum mencapai tingkat ketuntasan yang telah ditentukan.

Pada siklus I diperoleh persentase KBK aspek pengetahuan sebesar 76\% dengan kriteria ketuntasan cukup. Hal ini disebabkan karena masih banyak siswa yang kesulitan dalam menentukan informasi penting dan masih banyak siswa yang belum tepat dalam membuat kalimat tanya $5 \mathrm{~W}+1 \mathrm{H}$. Persentase KBK aspek keterampilan sebesar $69 \%$ dengan kriteria ketuntasan kurang. Hal ini disebabkan masih banyak siswa yang belum memahami isi bacaan sehingga dalam memaparkan belum memuat seluruh informasi penting. Pada siklus I rata-rata persentase sikap teliti siswa sebesar $62 \%$ dengan kriteria keberhasilan kurang, rata-rata persentase sikap percaya diri siswa sebesar 65\% dengan kriteria keberhasilan kurang, dan rata-rata persentase sikap tanggung jawab sebesar $62 \%$ dengan kriteria keberhasilan kurang. Rata-rata persentase karakter gemar membaca sebesar 62\% dengan kriteria keberhasilan kurang. Dari pelaksanaan siklus I hanya aspek pengetahuan yang telah mencapai ketuntasan secara klasikal. Hal ini sesuai dengan pendapat Sudjana (2010:3) yang menyatakan bahwa, jika suatu kelas telah mencapai $75-80 \%$ dari tujuan atau nilai yang seharusnya dicapai maka suatu kelas dapat dikatakan telah mencapai ketuntasan belajar secara klasikal.

Pada siklus II penerapan model SQ4R berbasis karakter gemar membaca sudah dilaksanakan dengan baik. Persentase KBK apek pengetahuan meningkat menjadi 89\% dengan kriteria keberhasilan baik, ini dikarenakan siswa sudah mengerti bagaimana cara menemukan informasi penting dan sudah mengerti mengenai penggunaan kalimat tanya $5 \mathrm{~W}+1 \mathrm{H}$. Persentase KBK apek keterampilan meningkat menjadi 89\% dengan kriteria ketuntasan baik, hal ini dikarenakan siswa telah memahami langkah-langkah memaparkan informasi dengan baik salain itu siswa telah mampu memahami isi teks narasi sejarah yang dibaca. Rata-rata persentase sikap teliti siswa meningkat menjadi 89\% dengan kriteria keberhasilan baik, ratarata persentase sikap percaya diri siswa meningkat menjadi 89\% dengan kriteria keberhasilan baik, rata-rata persentase sikap tanggung jawab siswa meningkat menjadi $82 \%$ dengan kriteria keberhasilan baik. Begitupun karakter gemar membaca yang mengalami peningkatan menjadi 88\% dengan kriteria keberhasilan baik.

Berdasarkan uraian di atas, dapat disimpulkan bahwa dengan menerapkan model SQ4R berbasis karakter gemar membaca pada materi memaparkan informasi penting teks narasi sejarah dapat meningkatkan hasil belajar sis akelas V SDN Sumberingij 04 Kabupaten Blitar. Keberhasilan penggunaan model SQ4R dalam meningkatkan hasil belajar telah dibuktikan dengan adanya penelitian terdahulu oleh Atmaja (2019) yang menunjukkan hasil penelitain pada siklus I sebesar 75\% dengan persentase KBK 55\% dan mengalami peningkatan pada 
siklus II menjadi $85 \%$ dengan persentase KBK 90\%. Pada siklus I persentase rata-rata nilai keterampilan 58\% dan mengalami peningkatan pada siklus II menjadi 83\%.

\section{Simpulan}

Penerapan model pembelajaran SQ4R berbasis karakter gemar membaca dalam meningkatkan hasil belajar materi memaparkan informasi penting teks narasi sejarah siswa kelas V SDN Sumberingin 04 Kabupaten Blitar sudah dilaksanakan dengan baik, sehingga berdampak pada peningkatan aktivitas guru dan aktivitas siswa dalam mengikuti pembelajaran. Hal ini dibuktikan dengan peningkatan aktivitas guru dan aktivitas siswa pada siklus I hingga siklus II. Peningkatan aktivitas guru dari siklus I hingga siklus II sebesar 14\%, sedangkan peningkatan aktivitas siswa dari siklus I hingga siklus II sebesar 16\%. Penerapan model SQ4R berbasis karakter gemar membaca juga dapat meningkatkan hasil belajar siswa. Hal ini dibuktikan dari hasil belajar siswa yang mengalami peningkatan dari siklus I hingga siklus II. Pada aspek pengetahuan peningkatan hasil belajar siklus I hingga siklus II sebesar 13\%. Pada aspek keterampilan mengalami peningkatan pada siklus I hingga siklus II sebesar $20 \%$. Pada aspek sikap terdapat peningkatan sikap teliti dari siklus I ke siklus II sebesar $27 \%$, begitupun dengan sikap percaya diri yang mengalami peningkatan dari siklus I ke siklus II sebesar 24\%, selain itu sikap tanggung jawab siswa juga mengalami peningkatan dari siklus I ke siklus II sebesar 20\%. Karakter gemar membaca siswa juga mengalami peningkatan dari siklus I hingga siklus II sebesar 26\%.

Berdasarkan simpulan hasil penelitian, maka disarankan saat menerapkan model pembelajaran SQ4R hendaknya guru mempersiapkan segala sesuatunya dengan matang baik dari segi rencana pelaksanaan pembelajaran beserta instrumen-instrumen terkait dan media pembelajaran yang akan digunakan. Selain itu hendaknya guru mampu memahami tahapantahapan pada model SQ4R agar tidak ada tahap yang terlewatkan, dan memanjamen waktu dengan baik agar kegiatan dapat berjalan sesuai dengan waktu yang ditentukan.

\section{Daftar Rujukan}

Atmaja, A. T. (2019). Peningkatan Hasil Belajar Memahami Isi dan Amanat Puisi Menggunakan Model SQ4R pada Siswa Kelas IV SDN Pojok 02 Kabupaten Blitar. Skripsi. Skripsi tidak diterbitkan. Malang: FIP Universitas Negeri Malang.

Arikunto, S., Suhardjono, \& Supardi. (2016). Penelitian Tindakan Kelas. Jakarta: PT Bumi Aksara.

Arikunto, S. (2013). Prosedur Penelitian: Suatu Pendekatan Praktik. Jakarta: PT Rineka Cipta.

Kemendikbud. (2018). Peraturan Mentri Pendidikan Nasional No. 37 Tahun 2018 tentang Kompetensi Inti dan Kompetensi Dasar Pelajaran. Jakarta: Kementrian Pendidikan dan Kebudayaan.

Mulyati, Y. (2015). Keterampilan Berbahasa Indonesia. Jakarta: Universitas Terbuka.

Rahayu, P. I. W., Zulaikha, S., Negara, I. G. A. O., \& Ke, S. P. M. (2014). Model Pembelajaran Kooperatif Tipe SQ4R Berbasis Keterampilan Proses Berpengaruh Terhadap Hasil Belajar IPA Siswa Kelas V SD Gugus Letkol Wisnu. MIMBAR PGSD Undiksha, 2(1).

Supriadin, S. (2018). Peningkatan Hasil Belajar Menulis Kalimat Efektif Dalam Paragraph Argumentasi Melalui Kegiatan Peer Correction Pada Siswa Kelas Viii Smpn 1 Ambalawi Kabupaten Bima Tahun Pelajaran 2014/2015. Jurnal Ilmiah Mandala Education (JIME), 2(1), 33-38.

Sohimin. (2016). 68 Model Pembelajaran Inovatif dalam Kurikulum 2013. Yogyakarta: R-Ruzz Media.

Sudjana, N. (2010). Penilaian Hasil Proses Belajar Mengajar. Bandung: PT Rosdakarya Offset.

Sogiyono. (2015). Metode Penelitian Pendidikan (Pendidikan Kuantitatif, Kualitatif, dan R\&D). Bandung: Alfabeta.

Susanto, A. (2016). Teori Belajar Pembelajaran di Sekolah Dasar. Jakarta: Prenamedia Group. 
Jurnal Pembelajaran, Bimbingan, dan Pengelolaan Pendidikan, 1(3), 2021, 195-203

Zainuddin, M. (2012). Membentuk Karakter Anak Bangsa. Malang: Universitas Wisnuwardhana Malang Press. 